DOI: $10.17516 / 1998-2836-0233$

УДК 542.65:66.093:661.887

\title{
Obtaining Bismuth-Potassium-Ammonium Citrate by Interaction of Bismuth Oxide with Potassium and Ammonium Citrates Solutions
}

\author{
Ekaterina S. Koledova*, \\ Alina A. Artamonova and Yuri M. Yukhin \\ Institute of Solid State Chemistry and Mechanochemistry SB RAS \\ Novosibirsk, Russian Federation
}

Received 18.04.2021, received in revised form 19.05.2021, accepted 07.06.2021

\begin{abstract}
The interaction of bismuth oxides of various morphologies with aqueous solutions of potassium and ammonium citrates has been studied by methods of X-ray phase, chemical analyzes and electron microscopy, and the conditions for the formation of bismuth-potassium-ammonium bismuth citrate have been determined.
\end{abstract}

Keywords: bismuth oxide, bismuth-potassium-ammonium citrate solution, bismuth-potassiumammonium citrate, obtaining.

Citation: Koledova E.S., Artamonova A.A., Yukhin Yu.M. Obtaining bismuth-potassium-ammonium citrate by interaction of bismuth oxide with potassium and ammonium citrates solutions, J. Sib. Fed. Univ. Chem., 2021, 14(2), $242-251$. DOI: $10.17516 / 1998-2836-0233$

(C) Siberian Federal University. All rights reserved

This work is licensed under a Creative Commons Attribution-NonCommercial 4.0 International License (CC BY-NC 4.0).

* Corresponding author E-mail address: naydenko@solid.nsc.ru 


\title{
Получение висмут-калий-аммоний цитрата взаимодействием оксида висмута \\ с растворами цитратов калия и аммония
}

\author{
Е. С. Коледова, А. А. Артамонова, Ю. М. Юхин \\ Институт химии твердого тела и механохимии СО РАН \\ Российская Федерация, Новосибирск
}

\begin{abstract}
Аннотация. Методами рентгенофазового, химического анализов и электронной микроскопии исследовано взаимодействие оксидов висмута различной морфологии с водными растворами цитратов калия и аммония, определены условия образования висмут-калий-аммоний цитрата висмута.
\end{abstract}

Ключевые слова: оксид висмута, раствор висмут-калий-аммоний цитрата, висмут-калийаммоний цитрат, получение.

Цитирование: Коледова, Е.С. Получение висмут-калий-аммоний цитрата взаимодействием оксида висмута с растворами цитратов калия и аммония / Е. С. Коледова, А. А. Артамонова, Ю. М. Юхин // Журн. Сиб. федер. ун-та. Химия, 2021, 14(2). C. 242-251. DOI: $10.17516 / 1998-2836-0233$

В последние годы особое внимание обращено на заболевания желудочно-кишечного тракта, такие как язвенная болезнь желудка и двенадцатиперстной кишки. По данным мировой статистики, язвенная болезнь распространена примерно у 5-10 \% взрослого населения [1]. На сегодняшний день в мировой практике существуют эффективные способы лечения язвенной болезни желудка и двенадцатиперстной кишки на основе висмутового препарата «Де-Нол» («Astellas Pharma Europe B.V.», Нидерланды) [2-6], основным активным компонентом которого является висмута трикалия дицитрат (субцитрат висмута, CBS), который представляет собой растворимые в воде комплексные калий-аммонийные соли висмута и лимонной кислоты.

Висмут-калий-аммоний цитрат, или коллоидный субцитрат висмута, предложено получать обычно путем суспензирования в воде цитрата висмута, последовательного добавления в суспензию водного раствора гидроксида калия, аммиака, трехзамещенного цитрата калия и лимонной кислоты. Для получения жидкого висмутсодержащего средства исходный раствор разбавляют водой в 5 раз до концентрации висмута в растворе 10,7 г/л [7]. Разработан способ получения коллоидного раствора основного трикалийзамещенного цитрата висмута [8] путем последовательного добавления при энергичном перемешивании в концентрированный (10,35\%-ный) водный раствор аммиака цитрата калия, цитрата висмута и цитрата аммония с последующим смешиванием полученного раствора с глицерином, сахарозой, этиловым спиртом и разбавлением водой до концентрации висмута 210 г/л. При получении твердых лекарственных субстанций предложено распылять исходный раствор при температуре не менее 328 К [9] или разбавлять раствор водой до достижения 33 \% по концентрации твердого вещества и подвергать распылительной сушке в токе воздуха при температуре $220-240{ }^{\circ} \mathrm{C}$ [10], либо концентрированию на 90 \% при быстром снижении давления до 27 гПа [11].

$$
-243-
$$


Обычно для получения висмут-калий-аммоний цитрата в качестве прекурсора используют цитрат [7] или средний нитрат висмута $[12,13]$. Однако технологии производства сложны, и их стоимость высока. Исходным сырьем для производства соединений висмута является металлический висмут, который растворяют в азотной кислоте и получают соединения висмута в результате переработки азотнокислых растворов. Предложен способ получения висмут-калий-аммоний цитрата из металлического висмута марки Ви1 (не менее 98,0 \% висмута), обычно используемого в синтезе его соединений. Способ основан на растворении гранул висмута в азотной кислоте, гидролитической очистке висмута от примесных металлов осаждением в виде оксогидроксонитрата, переводом его в цитрат в результате обработки раствором лимонной кислоты с последующим растворением цитрата висмута в растворе гидроксида калия в присутствии гидроксида аммония и кристаллизационной сушки полученного раствора при температуре $70{ }^{\circ} \mathrm{C}$ [14]. Поскольку синтез соединений висмута связан с переработкой азотнокислых растворов, то получаемые соединения содержат в виде примесей нитрат-ионы. Так, данные химического анализа образца цитрата висмута фирмы НЕК (Германия) показали, что содержание нитрат-ионов в нем составляет 0,4 \%. Анализ таблетки «Де-Нол», в которую помимо основного действующего вещества входят вспомогательные ингредиенты, показал содержание нитрат-ионов 0,18 \%. Известно, что нитрат-ионы под действием ферментов в организме превращаются в нитриты. Попадая в желудок, нитриты способны под действием желудочного сока превращаться в нитрозамины - вещества с широким спектром канцерогенного действия [15]. Для получения висмут-калий-аммоний цитрата с пониженным содержанием нитрат-ионов целесообразно исследовать возможность использования в качестве исходного соединения оксида висмута.

Целью данной работы является исследование процесса взаимодействия оксида висмута с растворами цитратов калия и аммония с получением висмут-калий-аммоний цитрата, обладающего повышенной степенью очистки от нитрат-ионов.

\section{Экспериментальная часть}

В работе использовали лимонную кислоту ГОСТ 3652-69, гидроксид калия ГОСТ 24363 80 квалификации «хч», гидроксид аммония ГОСТ 24147-80 квалификации «ос.ч», оксиды висмута: technical grade (НЕК, Германия) (I), varistor grade (НЕК, Германия) (II), высокочистый 99.9999 \% (ИНХ СО РАН, Россия) (III), ос.ч. 13-3 (ООО «Завод редких металлов», Россия) (IV). В работе использовали оксид висмута $(\mathrm{V})$, полученный путем обработки азотнокислого висмутсодержащего раствора (360 г/л Вi) 5M раствором гидроксида калия; а также оксид висмута (VI), полученный путем прокаливания оксокарбоната висмута состава $(\mathrm{BiO})_{2} \mathrm{CO}_{3}$ при температуре $(400 \pm 10){ }^{\circ} \mathrm{C}$.

Некоторые физические характеристики исследованных образцов оксидов висмута приведены в табл. 1.

Исследования взаимодействия оксида висмута с раствором лимонной кислоты, гидроксидов калия и аммония проводили при следующих условиях: навеска $\mathrm{Bi}_{2} \mathrm{O}_{3} 20$ г, мольное отношение $\left[\mathrm{Bi}^{3+}\right] /\left[\mathrm{Cit}^{3-}\right] /\left[\mathrm{K}^{+}\right]=1,0: 1,4: 1,8$. Исходный раствор готовили растворением лимонной кислоты в воде, добавлением к нему гидроксида калия при перемешивании до полного растворения и гидроксида аммония до $\mathrm{pH}$ 9. Синтез вели при перемешивании с использованием 
Таблица 1. Характеристики образцов оксидов висмута

Table 1. The characteristics of bismuth oxide samples

\begin{tabular}{|c|c|c|c|}
\hline Оксид висмут & Удельная поверхность, м $^{2} \Gamma$ & ${\text { Насыпная плотность, } г / \mathrm{cm}^{3}}_{\text {Размер частиц, мкм }}$ \\
\hline I & 0,02 & 5,485 & $20-50$ \\
\hline II & 0,78 & 1,385 & $1-5$ \\
\hline III & 0,03 & 4,684 & $10-100$ \\
\hline IV & 0,06 & 4,192 & $1-40$ \\
\hline V & 1,01 & 0,817 & $2-20$ \\
\hline VI & 3,28 & 1,016 & $0,5-1$ \\
\hline
\end{tabular}

верхнеприводной мешалки RW 11 basic (IKA, Германия). Условия синтеза: временной диапазон 0,5-6 ч, температура процесса $(22 \pm 2){ }^{\circ} \mathrm{C}$ и $(85 \pm 3){ }^{\circ} \mathrm{C}$, значение $\mathrm{pH}$ среды 9, которое поддерживали добавлением раствора гидроксида аммония. Отбор проб на висмут осуществляли каждые 30 мин. Полученный висмут-калий-аммоний-цитратсодержащий раствор фильтровали через воронку Бюхнера, переносили раствор в фарфоровую чашку и вели упаривание на плитке при температуре $(65 \pm 5){ }^{\circ} \mathrm{C}$, а затем сушили продукт в сушильном шкафу при данной температуре. Твердые продукты исследовали с использованием методов химического, рентгенофазового (РФА) анализов, электронной микроскопии. РФА продуктов проводили на порошковом дифрактометре Bruker D8 Advance (Германия) с использованием $\mathrm{Cu}_{\mathrm{Ka}}$-излучения при скорости вращения счетчика 0.5 град/мин. Содержание висмута в растворах и осадках определяли фотоколориметрическим методом с использованием КІ на приборе ФЭК-56М (Россия), твердые продукты взаимодействия предварительно растворяли в азотной кислоте $(1: 1)$. Определение анионов лимонной и азотной кислот в твердых продуктах реакций проводили после их перевода в раствор предварительной обработкой осадков раствором $2 \mathrm{M} \mathrm{NaOH}$ при $70-90{ }^{\circ} \mathrm{C}$. Для определения концентрации нитрат-ионов использовали колориметрический метод с салицилатом натрия [16], содержание цитрат-ионов определяли методом перманганатометрического титрования [17]. Электронно-микроскопические снимки получали с использованием сканирующего электронного микроскопа Hitachi TM 1000 (Япония). Количественный анализ ионов калия осуществляли методом пламенной фотометрии с использованием атомно-абсорбционного спектрометра AA240FS (США).

\section{Результаты и обсуждение}

Из данных фирмы Яманучи Юроп, состав субстанции висмута трикалия дицитрат в нормативном документе, зарегистрированном в РФ согласно П № 012626/01 от 26.01.2001 (НД 42-4717-06), представлен в виде $\left[\mathrm{Bi}_{6}(\mathrm{OH})_{6}\left(\mathrm{C}_{6} \mathrm{H}_{5} \mathrm{O}_{7}\right)_{4}\right]_{\mathrm{n}}$ с молекулярной массой $[2112]_{\mathrm{n}}$. При этом указано, что субстанция представляет собой высушенный коллоидный комплекс основного цитрата висмута, цитрата калия и аммония в аммиачном растворе. Однако содержания цитратов калия и аммония в нормативном документе не приведены, а их наличие способствует высокой (400 г/л) растворимости субстанции в воде. Содержания цитрата калия и аммония в субстанции приведены в следующих материалах. Так, по данным фирмы Польфа, субстанция препарата

$$
-245-
$$


«Вентрисол» (Польша), аналога препарата «Де-Нол», согласно НД 42-3250-94, имеет состав $\mathrm{Bi}_{6}$ $(\mathrm{OH})_{6}\left(\mathrm{C}_{6} \mathrm{H}_{5} \mathrm{O}_{7}\right)_{4} \mathrm{~K}_{3}\left(\mathrm{C}_{6} \mathrm{H}_{5} \mathrm{O}_{7}\right) \cdot \mathrm{NH}_{4} \mathrm{OH}_{\mathrm{n}}$. Проведенные в работе [18] исследования свидетельствуют, что молярное отношение ионов висмута к цитрат-ионам, ионам калия и аммония в субстанции препарата «Де-Нол» составляет соответственно $1.0: 1,40: 1,80: 1,22$. Исходя из вышесказанного, состав субстанции может быть представлен в следующем виде: $\left[\mathrm{Bi}_{6}(\mathrm{OH})_{6}\left(\mathrm{C}_{6} \mathrm{H}_{5} \mathrm{O}_{7}\right)_{4}\right]$ $\left.\left[\mathrm{K}_{3} \mathrm{C}_{6} \mathrm{H}_{5} \mathrm{O}_{7}\right]_{\mathrm{x}}\left[\left(\mathrm{NH}_{4}\right)_{3} \mathrm{C}_{6} \mathrm{H}_{5} \mathrm{O}_{7}\right)\right]_{\mathrm{y}}$, где $\mathrm{x}=3,2-4,2 ;$ a y $=0,8-1,8$ с содержанием активного компонента в пересчете на оксид висмута $38,5-42,0 \%$.

Оксиды висмута (I-VI) представляют собой моноклинную модификацию $\left(\alpha-\mathrm{Bi}_{2} \mathrm{O}_{3}\right)$, имеющую дифракционные максимумы со значениями $d / n$, равными 3.45, 3.25, 2.70, 1.96, 1.75 (PDF 41-1449). Кристаллическая структура оксида висмута имеет слоистый характер, где слои атомов висмута лежат параллельно плоскости (100), которая разделена слоями ионов кислорода зигзагообразно [19]. Данные электронной микроскопии (рис. 1) свидетельствуют, что оксид висмута (I) представляет собой шарообразные рельефные частицы диаметром 20-50 мкм, (II) сферолитоподобные частицы размерами 1-5 мкм, (III) - агломераты размерами 10-100 мкм,
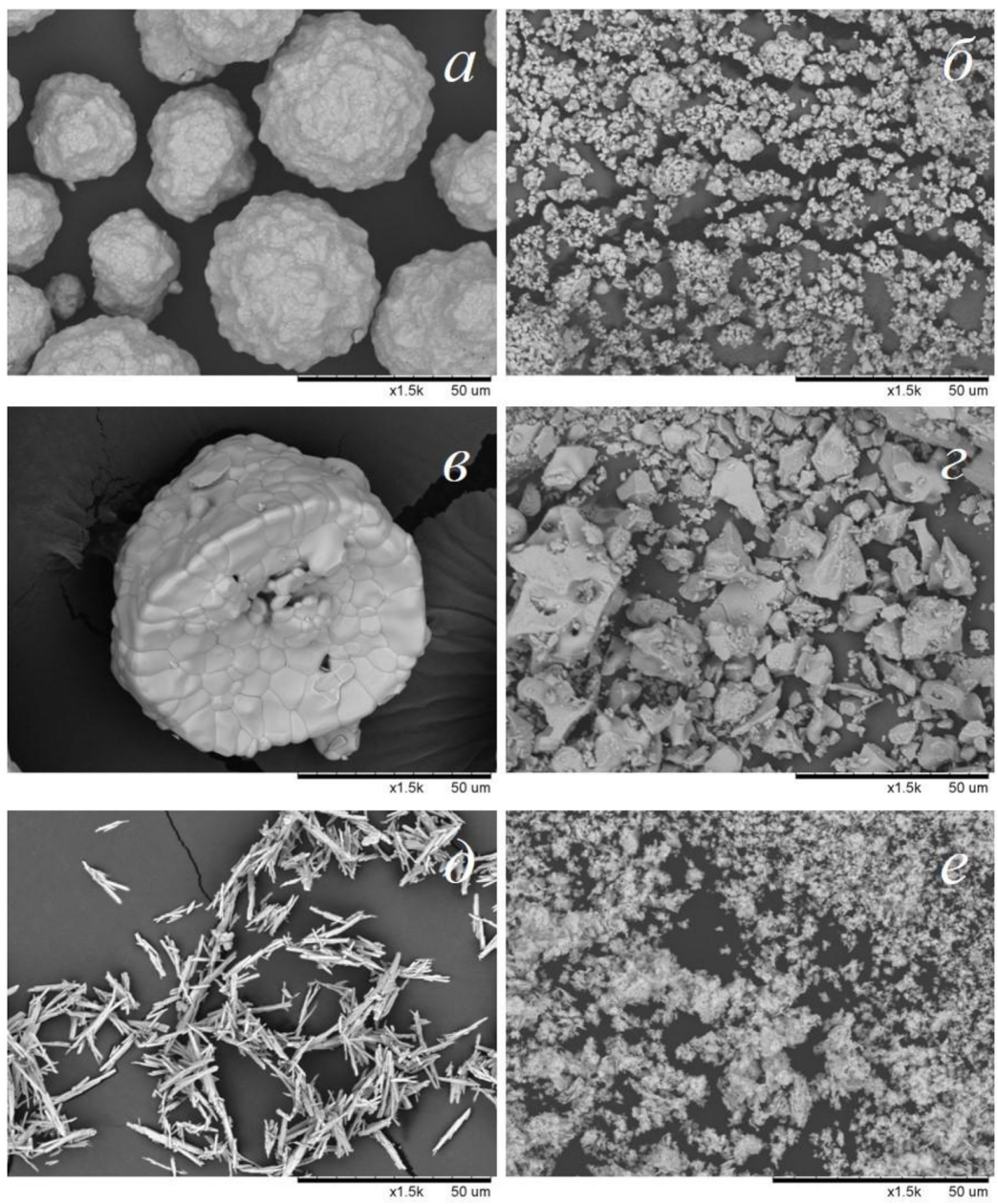

Рис. 1. Микрофотографии образцов оксидов висмута: I (a), II (б), III (в), IV (2), V (d), VI (e)

Fig. 1. Micrographs of bismuth oxide samples: I (a), II ( $(\sigma)$, III ( $(b)$, IV ( ()), V (d), VI (e) 
состоящие из скругленных частиц размерами 3-15 мкм, (IV) - оплавленные частицы неправильной формы с размерами от 1 до 40 мкм. Оксид висмута (V) представляет собой игольчатые кристаллы длиной 2-20 мкм и толщиной не более 2 мкм, a (VI) - слоистые дендритные кристаллы с размерами 0,5-1 мкм и толщиной слоев около 100 нм.

Выбор условий получения раствора висмут-калий-аммоний исследован с использованием оксида висмута (II), и показано, что при температурах $(22 \pm 2)^{\circ} \mathrm{C}$ и $(60 \pm 3){ }^{\circ} \mathrm{C}$ значения концентраций висмута в растворе не превышают 20 г/л даже через 4 ч, а при температуре $(85 \pm 3){ }^{\circ} \mathrm{C}$ эти значения достигают 260 г/л уже через 1 ч после начала процесса, тогда как в случае использования оксидов (I, III, IV) не удается достичь таких значений даже через 6 ч (рис. 2). Связано это, по-видимому, с большей удельной поверхностью оксида висмута (II), которая влияет на его реакционную способность. Максимальное содержание висмута в растворах, полученных при растворении в течение 6 ч оксидов (II), (III), (I) и (IV), составляет 260, 235, 200 и 150 г/л соответственно.

Результаты исследований взаимодействия оксидов висмута (V, VI) с растворами цитратов калия и аммония также представлены на рис. 2. При использовании в качестве прекурсора (V)


реакции (рис. 2, кривая 5), а в случае использования (VI) уже через 1 ч (рис. 2, кривая 6).

Полученный висмут-калий-аммоний-цитратсодержащий раствор может быть использован при получении субстанции для противоязвенного лекарственного средства путем его кристаллизации при $(65 \pm 5){ }^{\circ} \mathrm{C}$ (рис. 3 , дифрактограмма 1$)$ или распылительной сушки при $200{ }^{\circ} \mathrm{C}$ (рис. 3, дифрактограмма 2), а также жидкого висмутсодержащего средства. Электронно-микроскопические исследования продуктов, полученных путем кристаллизации (рис. 4, а) и распы-

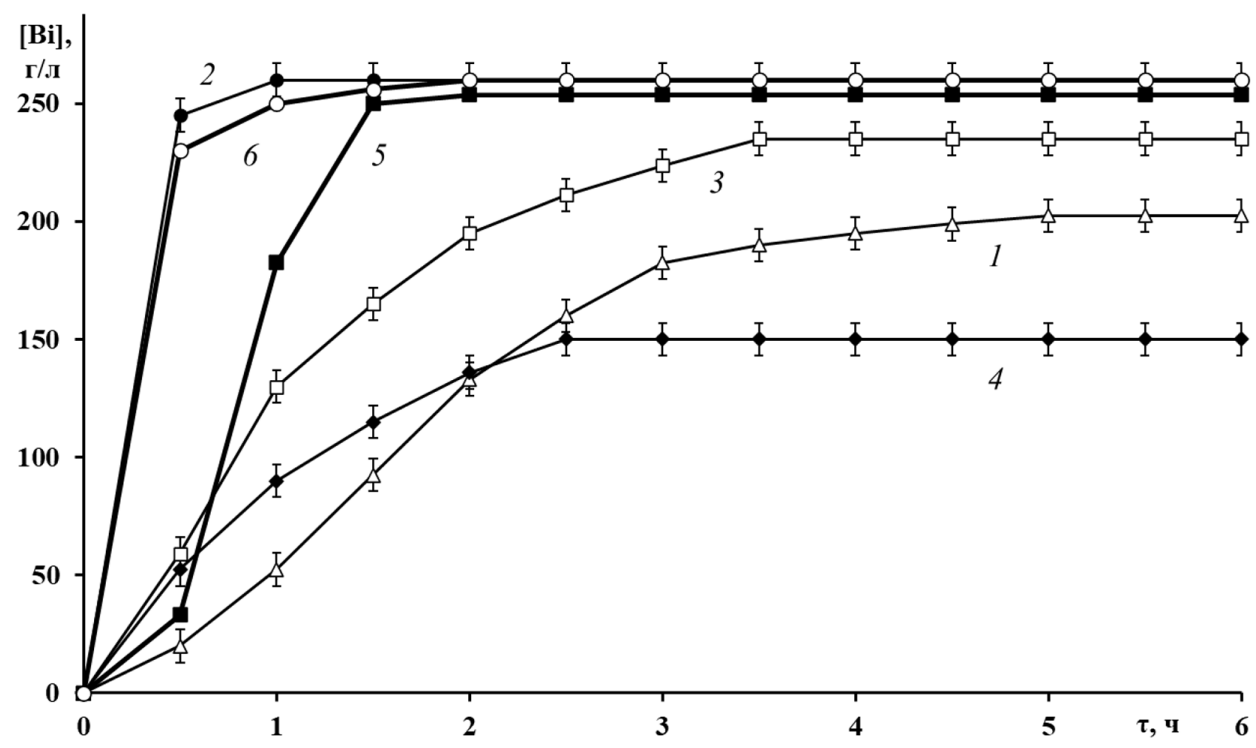

Рис. 2. Зависимость содержания висмута в растворе (1-6) от времени $(\tau$, ч) проведения процесса при использовании в качестве исходных оксидов (I-VI) висмута соответственно. Температура $(85 \pm 3){ }^{\circ} \mathrm{C}$

Fig. 2. The dependence of the content of bismuth in solution $(1-6)$ on the time $(\tau, h)$ of the process when using bismuth as initial oxides $(\mathrm{I}-\mathrm{VI})$, respectively. The temperature $(85 \pm 3){ }^{\circ} \mathrm{C}$ 


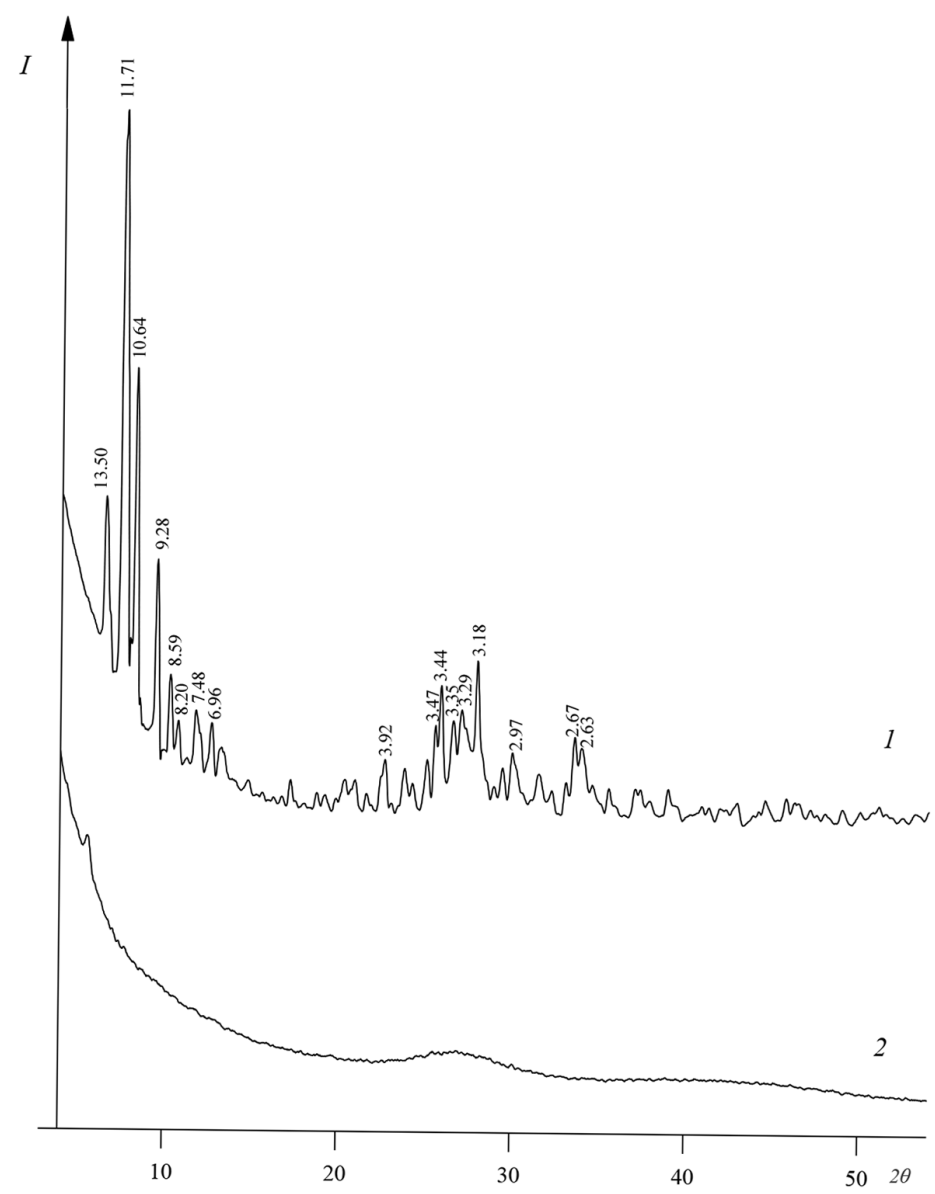

Рис. 3. Дифрактограммы образцов висмут-калий-аммоний цитрата, полученных кристаллизацией раствора (1) и распылительной сушкой (2)

Fig. 3. Diffraction patterns of bismuth-potassium-ammonium citrate samples obtained by crystallization of the solution (1) and spray drying (2)

лительной сушки (рис. 4, б) висмут-калий-аммоний-цитратсодержащего раствора, показали, что висмут-калий-аммоний цитрат, полученный в результате кристаллизации, представляет собой агрегаты размерами 5-50 мкм, состоящие из кристаллов неопределенной формы размерами 2-20 мкм. В то же время продукт, полученный в результате распылительной сушки раствора, представляет собой полые сферы диаметром 15-100 мкм и их обломки толщиной порядка 0,1-0,3 мкм.

Анализ образцов висмут-калий-аммоний цитратов (IIa), (Va) и (VIa), полученных с использованием оксидов висмута (II), (V) и (VI) соответственно, показал, что их химические составы соответствуют зарегистрированным в России субстанциям висмута трикалия дицитрата ФС 001165 ОСиБи Фармасьютикал С.Р.Л. (Испания), ФС 000303 5Н Плюс Любек ГмбХ (Германия) и ФС 001029 ФГБУН ИХТТМ СО РАН (Россия), а содержание в них нитрат-ионов не превышает 0,03 \% (табл. 2). Содержание нитрат-ионов в образцах исходных оксидов висмута составляет (в \%): 0,06 (II), 0,04 (V) и 0,04 (VI). 

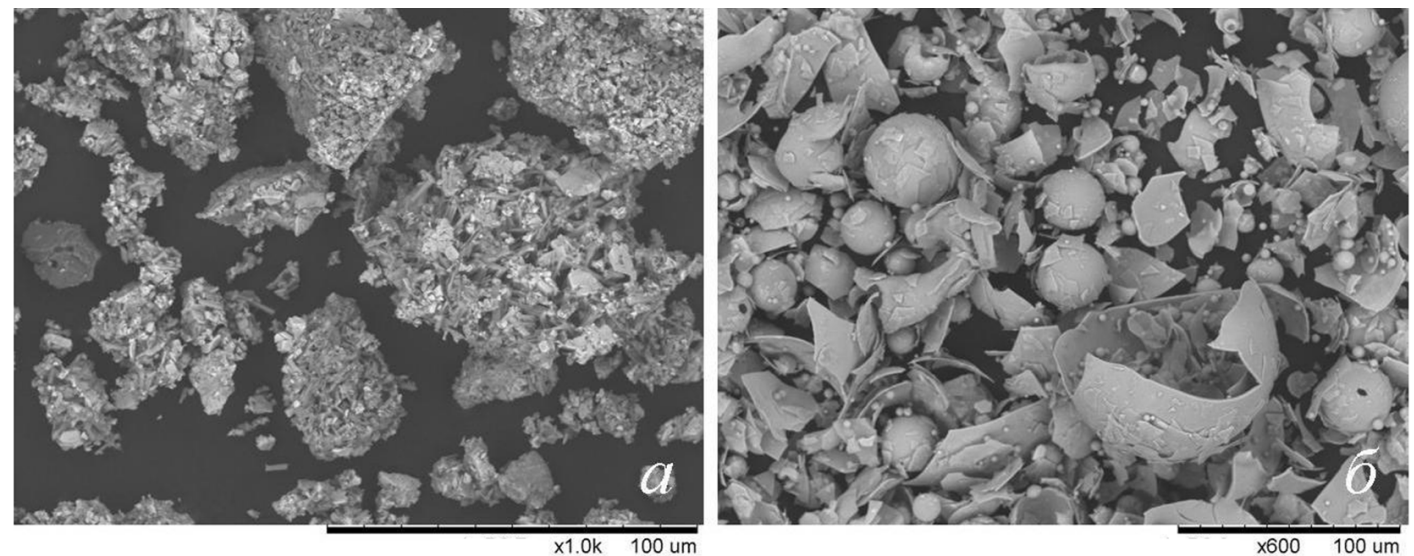

Рис. 4. Электронные микрофотографии образцов висмут-калий-аммоний цитрата, полученных кристаллизацией раствора (a) и распылительной сушкой (б)

Fig. 4. Micrographs of bismuth-potassium-ammonium citrate samples obtained by crystallization of the solution (a) and spray drying (б)

Таблица 2. Требования к зарегистрированным в России субстанциям висмута трикалия дицитрата и результаты анализа полученных образцов

Table 2. The requirements for the substances of bismuth tripotassium dicitrate registered in Russia and the results of the analysis of the obtained samples

\begin{tabular}{|c|c|c|c|c|c|}
\hline \multirow{2}{*}{ Висмута трикалия дицитрат } & \multicolumn{5}{|c|}{ Химический состав } \\
\cline { 2 - 6 } & {$\left[\mathrm{Bi}_{2} \mathrm{O}_{3}\right], \%$} & {$[\mathrm{~K}], \%$} & {$\left[\mathrm{Cit}^{3-}\right], \%$} & {$\left[\mathrm{NH}_{4}{ }^{+}\right], \%$} & {$\left[\mathrm{NO}_{3}{ }^{-}\right], \%$} \\
\hline ФС-001165 & $39,0-42,0$ & $10,8-13,9$ & - & $2,0-6,3$ & Не более 0,4 \\
\hline ФС-000303 & $38,2-40,6$ & $10,9-12,7$ & - & $2,0-6,0$ & - \\
\hline ФС-001029 & $38,5-42,0$ & $11,0-13,0$ & $41,0-48,0$ & $1,3-4,5$ & - \\
\hline IІа & 40,7 & 11,7 & 47,7 & 2,5 & 0,03 \\
\hline Va & 41,2 & 11,6 & 45,9 & 2,5 & 0,02 \\
\hline VIa & 40,8 & 11,9 & 46,1 & 2,2 & 0,02 \\
\hline
\end{tabular}

\section{Заключение}

1. Показана возможность получения висмут-калий-аммоний-цитратсодержащих растворов путем растворения лимонной кислоты в воде, добавлением к полученному раствору гидроксидов калия и аммония с последующим добавлением при температуре $(85 \pm 3){ }^{\circ} \mathrm{C}$ и $\mathrm{pH} 9$ оксида висмута. Установлено, что оксид висмута для получения висмут-калий-аммоний-цитратсодержащих растворов должен удовлетворять следующим требованиям: удельная поверхность более 0,7 м²/г и насыпная плотность менее 1,4 г $/ \mathrm{cm}^{3}$.

2. Показано, что висмут-калий-аммоний-цитратсодержащие растворы могут быть использованы для получения субстанции для противоязвенного лекарственного средства путем его кристаллизации при $(65 \pm 5){ }^{\circ} \mathrm{C}$ или распылительной сушки при $200{ }^{\circ} \mathrm{C}$, а также в виде жидкого висмутсодержащего средства. 
3. Содержание нитрат-ионов в образцах висмут-калий-аммоний цитратов не превышает $0,03 \%$, что позволяет рекомендовать данные продукты для получения чистого по содержанию нитрат-ионов висмут-калий-аммоний цитрата.

\section{Благодарности / Acknowledgements}

Работа выполнена в рамках государственного задания ИХТТМ СО РАН (проект AAAA-A17-117030310277-6).

This work was conducted within the framework of the budget projects AAAA-A17-117030310277-6 for ISSCM SB RAS.

\section{Список литературы / References}

1. Meurer L.N., Bower D.J. Management of Helicobacter pylori infection. American Family Physician 2002. № 65 (7). Р. 1327-1336.

2. Павлов А.И., Кириллов С.М., Пономаренко Д.С., Хаваншанов А.К., Фадина Ж.В., Бобкова И.В., Саввин В.Ю. Сравнительное исследование эффективности и безопасности использования препаратов коллоидного висмута трикалия дицитрата у больных с язвенной болезнью желудка и двенадцатиперстной кишки. Русский медицинский журнал 2016. Т. 24, № 26. С. 1782 1787. [Pavlov A.I., Kirillov S.M., Ponomarenko D.S., Khavanshanov A.K., Fadina Zh.V., Bobkova I.V., Savvin V.Yu. Comparative study of the efficacy and safety of the use of colloidal bismuth tripotassium dicitrate preparations in patients with gastric ulcer and duodenal ulcer. Russian medical journal. 2016. Vol. 24, No. 26. P. 1782-1787. (In Russ.)]

3. Бунова С.С., Мозговой С.И., Рыбкина Л.Б., Усачева Е.В., Назаров А.Н. Качество жизни у пациентов с хроническим Helicobacter pylori - ассоциированным гастритом при использовании эрадикационной терапии первой линии совместно с висмута трикалия дицитратом. Сибирский медицинский журнал 2013. Т. 118, № 3. C. 26-29. [Bunova S.S., Mozgovoy S.I., Rybkina L.B., Usacheva E.V., Nazarov A.N. Quality of life in patients with chronic Helicobacter pylori - associated gastritis when using first-line eradication therapy in conjunction with bismuth tripotassium dicitrate. Siberian Medical Journal 2013. Vol. 118, No. 3. P. 26-29. (In Russ.)]

4. Маслова Е.П., Бязрова В.В., Полищук В.Т., Ильяшенко Ю.Н. Оценка эффективности лечения заболеваний, обусловленных хеликобактерной инфекцией. Проблемы экологической и медииинской генетики и клинической иммунологии 2010. № 3 (99), C. 403-409. [Maslova E.P., Bazarova V.V., Polischuk V.T., Ilyashenko Yu.N. Evaluation of the effectiveness of treatment of diseases caused by Helicobacter pylori infection. Problems of ecological and medical genetics and clinical immunology 2010. Vol. 3 (99), P. 403-409. (In Russ.)]

5. Афанасьева Т.С., Перевозщикова Е.Э., Вахрушев Я.М. Клиническая эффективность Де-Нола у больных язвенной болезнью. Экспериментальная и клиническая гастроэнтерология 2008. № 4, С. 31-34. [Afanasyeva T.S., Perevozchikova E.E., Vakhrushev Ya.M. Clinical efficacy of De-Nol in patients with peptic ulcer. Experimental and clinical gastroenterology 2008. Vol. 4, P. 31-34. (In Russ.)]

6. Dore M.P., Graham D.Y., Mele R., Marras L., Nieddu S., Manca A., Realdi G. Colloidal Bismuth Subcitrate - Based Twice-a-Day Quadruple Therapy as Primary or Salvage Therapy for Helicobacter pylori Infection. The American journal of gastroenterology 2002. Vol. 97(4). P. 857-860.

$$
-250-
$$


7. Patent 292133 GDR. Berthold H., Michalczyk D., Urban G., Dr. R. Pfleger Chemisch Fabrik $\mathrm{GmbH}$. Liquid bismuth-containing medicinal product, method of its production and use. Publ. Date 25.07.1991.

8. Patent 151583 PPR. Zielinsky S., Pfeiffer B., Domanska D. A method of obtaining a colloidal solution of basic tripotassium-substituted citrate. Publ. Date 29.03.1991.

9. Patent 155743 Poland. Zielinsky S., Pfeiffer B., Domanska D. Method of obtaining basic tripotassium-bismuth-citrate. Publ. Date 30.09.1992.

10. Patent 83-01001WO. Bos P.J.H., Endel D.J.C., De J.H. Bismuth containing composition for treating peptic ulcers. Publ. Date 31.03.1983.

11. Patent 148307 Poland. Lemiesz L., Marszal K., Plaszynski L. Sposob otrzymywania cytrynianu Bizmutano-amonowo-potasowego. Publ. Date 31.03.1990.

12. Patent 280575 Czech. Nováček A., Voves J., Holá V., Dlabač A., Gattnar O. Chemopharma a.s. Praha, CZ. Method of obtaining basic bismuth citrate. Publ. Date 14.10.1991.

13. Patent 547096 Spain. Salvador D.D. Antiulcer drug. Publ. Date 16.03.1986.

14. Патент 2530897 РФ. Юхин Ю.М., Афонина Л.И., Ляхов Н.З., Даминов А.С., Найденко Е.С. Способ получения висмут-калий-аммоний цитрата. Опубл. 20.10.14. [Patent 2530897 RF. Yukhin Yu.M., Afonina L.I., Lyakhov N.Z., Daminov A.S., Naidenko E.S. Method for producing bismuth-potassium-ammonium citrate. Publ. Date 20.10.2014. (In Russ.)]

15. Галачиев С. М., Макоева Л. М., Джиоев Ф. К., Хаева Л. Х. Возможности эндогенного образования нитрозаминов в желудочном соке in vitro. Известия Самарского научного иенmpa PAH 2011. T. 13, № 1 (7). C. 1678-1680. [Galachiev S.M., Makoeva L.M., Dzhioev F.K., Khaeva L.Kh. Possibilities of endogenous formation of nitrosamines in gastric juice in vitro. Bulletin of the Samara Scientific Center of the Russian Academy of Sciences 2011. T. 13, No. 1 (7). P. 1678-1680. (In Russ.)]

16. Лурье Ю.Ю. Аналитическая химия промышленных сточных вод. М.: Химия, 1994. 448 c. [Lurye Yu.Yu. Analytical chemistry of industrial wastewater. Moscow: Chemistry, 1994. 448 p. (In Russ.)]

17. Эшворт М.Р.Ф. Титрометрические методы анализа органических соединений. Часть II. Методы косвенного титрования. М.: Химия, 1972. 1108 c. [Eshworth M.R.F. Titrimetric methods for the analysis of organic compounds. Part II. Methods of indirect titration. M.: Chemistry, 1972. 1108 p. (In Russ.)]

18. Юхин Ю.М., Найденко Е.С., Карпова Е.М., Фрумин Л.Е., Савельева К.Р., Хлябич Г.Н., Шестаков В.Н. Противоязвенный препарат на основе субстанции висмута(III) калия дицитрата. Бутлеровские сообщения. 2014. Т. 38, № 4. C. 87-93. [Yukhin Yu.M., Naidenko E.S., Karpova E.M., Frumin L.E., Savelyeva K.R., Khlyabich G.N., Shestakov V.N. Antiulcer drug based on the substance of bismuth (III) potassium dicitrate. Butlerov Communications. 2014. Vol. 38(4). P. 87-93. (In Russ.)]

19. Mehring M. From molecules to bismuth oxide-based materials: Potential homo- and heterometallic precursors and model compounds. Coordination Chemistry Reviews 2007. V. 251. P. 974-1006. 